\title{
Pengaruh Lingkungan Kerja Terhadap Kinerja Pegawai Pada Kantor Badan Perencanaan Pembangunan Daerah Kabupaten Batang Hari
}

\author{
Budi Darma, Azwar Anas \\ Sekolah Tinggi Ilmu Ekonomi Graha Karya
}

\begin{abstract}
This study entitled the influence of the work environment on employee performance at the Office of the Regional Development Planning Board of Batang Hari Regency. In this study will be tested how much influence the work environment on employee performance. In analyzing data, in this study using Path Analysis and test. This study has the same population and sample of 63 people. Data retrieval is done by distributing question questionnaires. Based on the discussion it can be concluded that the influence of the work environment on performance is 34.45\%. And the Work Environment has a partial and significant effect on employee performance at the Office of the Regional Development Planning Board of Batang Hari Regency.
\end{abstract}

Keyword: the influence of the environment; employee performance; regional development

DOI: 10.33087 /ekonomis.v3i1.55

\section{PENDAHULUAN}

Peranan sumber daya manusia dalam organisasi, baik organisasi yang menganut sistem pelayanan non profit maupun profit sangat penting. Sebab tanpa sumber daya manusia maka apapun bentuk peralatan tehnologi dan secanggih apapun peralatan tehnologi yang dimiliki oleh organisasi tersebut tidak akan dapat difungsikan secara optimal (Adisetiawan dan Asmas, 2018). Di samping itu, jika asset ini terabaikan bukan tidak mungkin akan mengganggu aktivitas organisasi secara keseluruhan. Mengingat pentingnya peranan sumber daya manusia ini dalam suatu organisasi tentunya sumber daya manusia tersebut perlu untuk dikelola sedemikian rupa, dan hal ini merupakan bagian penting dari pekerjaan menejemen organisasi yang bersangkutan. Proses manejemen sumber daya manusia pada akhirnya harus diukur dari segi seberapa efektif para menejer mengelola sumber daya manusia yang dimiliki. Dalam konteks ini, pengelolaan sumber daya manusia yang efektif tercermin dari produktivitas atau kinerja yang disumbangkan oleh pegawai. Dengan demikian dapatlah dikatakan bahwa kinerja dari para pegawai merupakan diantara isu-isu pokok yang senantiasa dihadapi oleh menejemen organisasi. Karena itu, diantara tugas-tugas para menajer yang sangat penting adalah menggerakkan para pegawai guna memberi kontribusi bagi keberhasilan organisasi. (Adisetiawan, 2017)

Aktivitas untuk menentukan berhasil tidaknya suatu pekerjaan yang dilakukan organisasi diperlukan pengelolaan dan perencanaan manajemen yang baik. Manajemen adalah ilmu dan seni mengatur proses pemanfaatan sumber daya manusia dan sumber-sumber lainnya secara efektif dan efisien untuk mencapai suatu tujuan tertentu. Sumber daya manusia merupakan hal yang sangat penting dalam kegiatan organisasi. Adisetiawan (2011) mengungkapkan bahwa waktu, tenaga, dan kemampuannya benar-benar dapat dimanfaatkan secara optimal bagi kepentingan organisasi, maupun bagi kepentingan individu. Diperlukan adanya suatu pelatihan agar pegawai dapat melakukan aktivitas kerja dengan efektif sehingga sumber daya manusia dapat mencapai kinerja yang baik. Organisasi menurut pelaksanaannya perlu melakukan suatu penilaian kinerja pegawai. Kinerja merupakan jawaban dari berhasil tidaknya tujuan organisasi. Kinerja pegawai diketahui dari seberapa jauh pegawai melaksanakan tugas sesuai tanggung jawabnya. Menurut Mangkunegara (2009) kinerja adalah hasil kerja secara kualitas dan kuantitas yang dicapai oleh seseorang pegawai dalam melaksanakan tugasnya sesuai dengan tanggungjawab yang diberikan kepadanya. Hasil kinerja yang baik salah satunya apabila pegawai mampu memberikan pelayanan yang baik kepada masyarakat.

Kinerja juga bisa menjadi gambaran kualitas dari organisasi. Organisasi yang memiliki kinerja baik, tentu saja akan memiliki kualitas manajemen yang baik pula, maka tidak bisa dipungkiri bahwa kinerja termasuk pula ke dalam hal yang sangat penting dalam mencapai tujuan organisasi. Melalui Kantor Badan Perencanaan Pembangunan Daerah (Bappeda) Kabupaten Batang Hari, Jambi, pemerintah daerah melakukan perancanaan pembangunan pada wilayah dan daerah kerjanya. Tugas Bappeda adalah membangun daerah berdasarkan penelitian bidang pembangunan 
dan kemasyarakatan, penyusunan pola dasar daerah, penyusunan program pembangunan tahunan, hingga perancangan anggaran pembangunan. Terkait tugas dan fungsi tersebut, maka Bappeda juga memiliki peran wewenang persuratan dan perizinan pembangunan perumahan dan pertokoan bagi developer, salah satu surat tersebut adalah Izin Prinsip untuk perizinan membangun bangunan baik rumah dan property lain dan surat Keterangan Rencana Umum Tata Ruang (RUTR).

Salah satu faktor yang juga harus diperhatikan suatu organisasi/instansi dalam meningkatkan kinerja adalah dengan memperhatikan kondisi lingkungan kerja. Lingkungan kerja adalah segala sesuatu yang berada disekitar pegawai yang mempengaruhi dirinya dalam menjalankan dan menyelesaikan tugas-tugas yang diberikan kepadanya. Lingkungan kerja dalam suatu organisasi/instansi sangat penting untuk diperhatikan unsur pimpinan. Lingkungan kerja yang memberikan rasa nyaman dapat meningkatkan kinerja pegawai, sebaliknya lingkungan kerja yang tidak memadai dapat menurunkan kinerja pegawai. Lingkungan kerja meliputi pewarnaan, kebersihan, pertukaran udara, penerangan, musik, keamanan, dan kebisingan. Lingkungan kerja dinyatakan baik atau sesuai apabila manusia dapat melaksanakan kegiatan secara optimal, sehat , aman, dan nyaman. Lingkungan kerja yang kurang baik dapat menuntut tenaga kerja dan waktu yang lebih banyak dan tidak mendukung diperolehnya rancangan sistem kerja yang efisien (Sedarmayanti, 2009).

\section{Tinjauan Pustaka \\ Lingkungan Kerja}

Lingkungan kerja merupakan suatu lingkungan dimana karyawan bekerja, sedangkan kondisi kerja merupakan kondisi dimana karyawan tersebut bekerja. Dengan demikian, sebenarnya kondisi kerja termasuk salah satu unsur lingkungan kerja. Lingkungan kerja adalah segala sesuatu yang berada disekitar karyawan yang mempengaruhi dirinya dalam menjalankan dan menyelesaikan tugas-tugas yang diberikan kepadanya dalam suatu wilayah. Adisetiawan (2016) menjelaskan bahwa lingkungan kerja adalah segala sesuatu yang ada disekitar pekerja yang dapat mempengaruhi dalam bekerja meliputi pengaturan penerangan, pengontrolan suara gaduh, pengaturan kebersihan tempat kerja dan pengaturan keamanan tempat kerja. Menurut Sedarmayanti (2009), ada beberapa indikator yang dapat digunakan dalam tolok ukur lingkungan kerja, antara lain sebagai berikut: penerangan, suhu udara, suara bising, penggunaan warna, ruang gerak yang diperlukan, keamanan kerja, dan hubungan sesama rekan kerja

\section{Kinerja}

Menurut Gomes (2003) mengemukakan definisi kinerja pegawai sebagai ungkapan seperti output, efisiensi serta efektivitas sering dihubungkan dengan produktivitas. Sedangkan menurut Bernardin dalam Robbins (2002) kinerja konsep yang bersifat universal yang merupakan efektivitas operasional suatu organisasi, bagian organisasi dan bagian karyawannya berdasarkan standar dan kriteria yang telah ditetapkan sebelumnya, karena organisasi ada dasarnya dijalankan oleh manusia, maka kinerja sesungguhnya merupakan perilaku manusia dalam memainkanperan yang mereka lakukan dalam suatu organisasi untuk memenuhi standar perilaku yang telah ditetapkan agar membuahkan tindakan dan hasil yang diinginkan. Ada beberapa indikator pengukuran kinerja pegawai menurut Gomes (2003) adalah sebagai berikut :

1. Quantity of work: Jumlah kerja yang dilakukan dalam suatu periode waktu yang ditentukan.

2. Quality of work : kualitas kerja yang dicapai berdasarkan syarat-syarat kesesuaian dan kesiapannya.

3. Job Knowledge : Luasnya pengetahuan mengenai pekerjaan dan keterampilannya.

4. Creativeness : Keaslian gagasan-gagasan yang dimunculkan dari tindakan-tindakan untuk menyelesaikan persoalan-persoalan yang timbul. 
5. Cooperation : kesediaan untuk bekerja sama dengan orang lain (sesama anggota organisasi).

6. Dependability : Kesadaran dan dapat dipercaya dalam hal kehadiran dan penyelesaian kerja tepat pada waktunya.

7. Initiative : Semangat untuk melaksanakan tugas-tugas baru dan dalam memperbesar tanggung jawabnya.

8. Personal Qualities : Menyangkut kepribadian, kepemimpinan, keramah-tamahan, dan integritas pribadi.

\section{METODE}

Adapun objek penelitian dari penelitian ini adalah Kantor Badan Perencanaan Pembangunan Daerah Kabupaten Batang Hari. Populasi dalam penelitian ini adalah keseluruhan pegawai yang bekerja pada Kantor Badan Perencanaan Pembangunan Daerah Kabupaten Batang Hari yang tercatat yang berjumlah 63 orang. Untuk menentukan besarnya sampel yang akan dijadikan responden, peneliti mengacu pada pendapat Arikunto (2010). Arikunto dalam melakukan perhitungan ukuran sampel yang diperoleh menyatakan bahwa apabila populasi di bawah 100 maka diambil semuanya untuk dijadikan sampel. Tapi jika populasi di atas 100 maka diambil 1025\%. Dalam hal ini populasi berjumlah 63 orang, maka sampel yang diambil keseluruhan dari populasi yang berarti jumlah sampel sebanyak 63 orang. Data primer adalah data yang diperoleh dengan cara penelitian dilapangan, yaitu data diperoleh dari para pegawai Kantor Badan Perencanaan Pembangunan Daerah Kabupaten Batang Hari dengan melakukan penyebaran kuesioner. Data Sekunder adalah data yang diperoleh dengan cara mengadakan penelitian kepustakaan dan dokumen kepegawaian, dokumen kerja, dan dokumen lainnya yang berasal dari Kantor Badan Perencanaan Pembangunan Daerah Kabupaten Batang Hari. Data-data yang didapat bersumber dari dalam (internal) Kantor Badan Perencanaan Pembangunan Daerah Kabupaten Batang Hari, seperti: data para pegawai, dan data lain yang mendukung. Sedangkan data eksternal bersumber dari literatur-literatur yang berkaitan dengan masalah yang diteliti. Dalam memperoleh data, digunakan metode Penelitian Lapangan yaitu dengan menggunakan perangkat kuesioner terstruktur yang diajukan pada responden. Perangkat kuesioner yang disebar ditarik kembali dan dilakukan tabulasi tanggapan responden. Kemudian pengumpulan data juga dilakukan dangan penelitian kepustakaan dengan tujuan mengumpulkan data dan teori yang relevan. Dalam menganalisis dan menginterpretasikan data dan informasi dalam penelitian ini, penulis menggunakan pendekatan analisa statistik/verifikatif.

\section{Path Analysis}

Untuk menjawab permasalahan menggunakan analisis jalur (Path Analysis) yang merupakan suatu metode pendekomposisian korelasi ke dalam bagian-bagian yang berbeda untuk menginterprestasikan suatu pengaruh/efek. Metode Path Analysis ini juga digunakan untuk menelaah hubungan antara model kausal yang dirumuskan atas dasar pertimbangan teoritis dan pengetahuan tertentu. Hubungan kausal selain didasarkan pada data, juga didasarkan pada pengetahuan, perumusan hipotesis dan analisis logis, sehingga dapat dikatakan Path Analysis ini dapat digunakan untuk menguji seperangkat hipotesis kausal serta untuk menafsirkan hubungan tersebut.
Lingkungan Kerja (X)

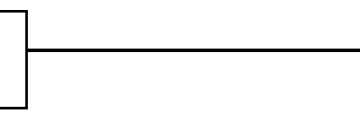
Kinerja (Y)

\section{Gambar 1. Analisis Jalur}


Untuk persamaan hubungan struktural diagram jalur diatas dinyatakan dengan persamaan sebagai berikut:

1. Pengaruh $X$ terhadap $Y$, Pengaruh langsung

$\mathrm{X} \rightarrow \mathrm{Y}=\mathrm{PYX}$. PYX

2. Uji $\mathrm{t}$, uji $\mathrm{t}$ digunakan untuk melihat pengaruh secara parsial antara variabel eksogen dan variabel endogen. Berdasarkan hasil pengujian uji t, maka akan diperoleh suatu hasil berupa thitung yang akan dibandingkan dengan t-tabel. Adapun rumus uji t adalah sebagai berikut :

$$
t_{\text {hitung }}=\frac{r \sqrt{n-2}}{\sqrt{1-r^{2}}}
$$

Keterangan $: t=$ Nilai $t_{\text {hitung }} ; r=$ Koefisien korelasi $\left(r_{\text {hitung }}\right) ; n=$ Jumlah responden

- Nilai $t_{\text {hitung }}<t_{\text {tabel }}$ berarti tidak terdapat pengaruh secara parsial.

- Nilai $t_{\text {hitung }}>t_{\text {tabel }}$ berarti terdapat pengaruh secara parsial.

\section{HASIL}

\section{Analisis Jalur Pengaruh Lingkungan Kerja terhadap Kinerja pada Kantor Badan Perencanaan Pembangunan Daerah Kabupaten Batang Hari}

analisis ini, diperlukan nilai koefisien jalur lingkungan kerja terhadap kinerja. Berikut koefisien keseluruhan jalur dalam penelitian ini :

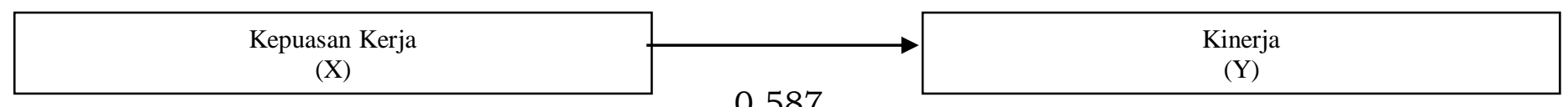

\section{Gambar 2. Koefisien Jalur}

Berdasarkan pada gambar di atas, dapat kita lakukan perhitungan mengenai pengarauh fasilitas kerja dan kompetensi terhadap kinerja melalui kepuasan kerja. Berikut adalah perhitungan pengaruhnya :

Pengaruh Kepuasan Kerja terhadap kinerja

$\mathrm{X}_{1} \quad \rightarrow \quad Z=(\mathrm{PYX})(\mathrm{PYX})=0,587 \times 0,587=0,3445$

Uji t

Hipotesis menyatakan kepuasan kerja berpengaruh secara parsial dan signifikan terhadap kinerja pegawai pada Kantor Kelurahan Sekecamatan Muara Bulian Kabupaten Batang Hari. Berikut hasil pengujiannya :

Tabel 1. Nilai t Hitung dan $t$ Tabel Lingkungan terhadap Kinerja

\begin{tabular}{llll}
\hline Variabel & t hitung & t tabel & Sig. \\
\hline Kepuasan Kerja & 3,297 & 1,67065 & 0,000 \\
\hline
\end{tabular}

Sumber : Data diolah

Tabel 1 di atas, dapat diketahui bahwa nilai t hitung untuk kepuasan kerja sebesar 3,297, nilai t tabel sebesar 1,67065, dan nilai Signifikan di bawah 0,05 $(0,000)$. Nilai t hitung $>$ nilai t tabel (3,297>1,67065), maka lingkungan kerja berpengaruh secara parsial dan signifikan terhadap kinerja pegawai pada Kantor Badan Perencanaan Pembangunan Daerah Kabupaten Batang Hari. 


\section{SIMPULAN}

Berdasarkan pada pembahasan dapat ditarik kesimpulan bahwa pengaruh lingkungan kerja terhadap kinerja sebesar 34,45\%. Dan Lingkungan Kerja berpengaruh secara parsial dan signifikan terhadap Kinerja pegawai pada Kantor Badan Perencanaan Pembangunan Daerah Kabupaten Batang Hari.

\section{DAFTAR PUSTAKA}

Adisetiawan, R., 2011, Relevansi Nilai Informasi Akuntansi pada Indeks LQ45, Jurnal Akuntabilitas, 1(1), 119-136

Adisetiawan,R., 2016, Faktor yang Mempengaruhi Lulusan SMA dalam Memilih Fakultas Ekonomi Prigram Studi Manajemen Universitas Batanghari, Jurnal Universitas Batanghari Jambi, 16(3), 1-11

Adisetiawan, R., dan Asmas, Denny, 2018, Hubungan EVA dan MVA sebagai Alat Pengukur Kinerja Perusahaan serta Pengaruhnya Terhadap Harga Saham, Jurnal Universitas Batanghari Jambi, 12(1), 12-18

Adisetiawan, R., 2017, Kajian Persepsi Pemilik Usaha Kecil dan Menengah (UKM) terhadap Laporan Keuangan, Jurnal Universitas Batanghari Jambi, 13(4), 162-173

Gomes, Faustino Cardoso. 2003. Manajemen Sumber Daya Manusia. Yogyakarta : ANDI

Mangkunegara Anwar. P., 2009. Manajemen Sumber Daya Manusia Perusahaan. Bandung: PT. Remaja Rosda Karya.

Robbins SP dan Judge. 2002. Perilaku Organisasi. Jakarta : Salemba Empat

Sedarmayanti, 2009, Sumber Daya Manusia dan Produktivitas Kerja, Mandar Maju, Bandung.

Suharsimi, Arikunto. 2010. Prosedur Penelitian Suatu Pendekatan Praktik. Jakarta: Rineka Cipta 